\title{
ISOLASI SENYAWA AKTIF DAN UJI AKTIVITAS EKSTRAK JAHE MERAH (ZINGIBER OFFICINALE) SEBAGAI IMUNOMODULATOR
}

\author{
Masniah $^{1}$, Jafril Rezi ${ }^{2}$, Ahmad Purnawarman Faisal ${ }^{3}$ \\ 1,2,3 Poltekkes Kemenkes Medan \\ Email korespondensi: mkesapt@gmail.com
}

\begin{abstract}
ABSTRAK
Jahe merah (Zingiber officinale) mengandung banyak senyawa kimia yang mempunyai banyak aktivitas. Penelitian ini bertujuan untuk mengetahui senyawa aktif dari Zingiber officinale dan Aktivitas Imunomodulator yang dapat meningkatkan fagositosis sel makrofag dan Proliferasi Sel limfosit. Ektrak Jahe Merah di identifikasi senyawa dengan menggunakan GC-MS. Parameter Aktivitas Imunostimulator adalah fagositosis makrofag dan proliferasi limfosit, sediaan dibuat dalam beberapa konsentrasi ekstrak. Penelitian ini adalah penelitian eksperimental di laboratorium. Penelitian meliputi jahe merah segar, dibuat menjadi ekstrak etanol, dikeringkan, Hasilnya dibuat suspensi, ekstrak lalu diberi pada sel makrofag (pengujian fagositosis) dan sel limfosit (pengujian proliferasi) secara in-vitro untuk diujikan efek imunomodulator. Hasil penelitian menunjukkan bahwa ekstrak yang paling aktif dalam aktivitas fagositosis makrofag adalah konsentrasi ekstrak $500 \mathrm{ppm}$. Sedangkan aktivitas proliferasi sel limfosit ditunjukkan oleh konsentrasi kelompok A (Sel, Ekstrak 500 ppm, MK, Engerik). Kandungan senyawa aktif yang terdapat pada ekstrak etanol jahe merah diduga Geraniol.
\end{abstract}

Kata kunci : Jahe, Zingiber officinale, imunostimulator 


\title{
ISOLATION OF ACTIVE COMPOUNDS AND ACTIVITY TEST OF RED GINGER EXTRACT (ZINGIBER OFFICINALE) AS IMUNOMODULATOR
}

\begin{abstract}
Red ginger (Zingiber officinale) contains many chemical compounds that have many activities. This study aims to determine the active compounds of Zingiber officinale and immunomodulatory activity that can increase the phagocytosis of macrophage cells and lymphocyte cell proliferation. Red ginger extract compounds were identified using GC-MS. The parameters of immunostimulatory activity were macrophage phagocytosis and lymphocyte proliferation, the preparations were made in several extract concentrations. This research is an experimental study in the laboratory. The research included fresh red ginger, made into ethanol extract, dried. The results were made a suspension, the extract was then given to macrophage cells (phagocytosis testing) and lymphocyte cells (proliferation testing) in vitro to test the immunomodulatory effect. The results showed that the most active extract in macrophage phagocytosis activity was the extract concentration of $500 \mathrm{ppm}$. While the activity of lymphocyte proliferation was shown by the concentration of group A (Cell, 500 ppm extract, MK, Engerik). The active compound contained in the ethanol extract of red ginger is thought to be Geraniol
\end{abstract}

Keywords : Red Ginger, Zingiber officinale, immunostimulator

\section{PENDAHULUAN}

Indonesia merupakan negara kaya dengan keanekaragaman hayati $(A$ Mega Biodiversity Country) dimana terdapat lebih kurang 30.000 jenis tanaman yang tersebar di seluruh tanah air, sekitar 9.600 spesies berkhasiat obat dan kurang lebih 300 spesies digunakan sebagai bahan pengobatan tradisional oleh industri obat tradisional. Oleh karena itu keanekaragaman hayati yang ada di Indonesia merupakan aset dan sumberdaya yang harus dipelihara dan dikelola untuk dapat menjadi warisan leluhur dan bermanfaat bagi masyarakat untuk pemeliharaan kesehatan (Kementrian Kesehatan RI, 2012).
Beberapa tanaman yang sudah digunakan masyarakat secara empiris seperti Biji Pala (Myristicae semen) dan jahe merah (Zingiberis officinale) untuk mengatasi inflamasi (radang,bengkak). Penyakit rematik menyebabkan inflamasi, kekakuan, pembengkakan, dan rasa sakit pada sendi, otot, tendon, ligamen, dan tulang. (Tjay,2012)

Jahe merah merupakan jenis tanaman herbal yang tergolong kedalam jenis tanaman rimpang, jahe sering dijadikan sebagai bahan untuk membuat minuman atau jamu tradisional. Jahe adalah jenis rempah-rempah yang 
memiliki kandungan senyawa yang sangat berkhasiat untuk mengatasi berbagai jenis penyakit seperti rematik, batuk sudah dikenal sejak jaman dulu hingga sekarang. Jahe merah mengandung zingiberena, bisabolena dan kamfer yang berkhasiat sebagai anti inflamasi (S.Dalimarta, 2008).

Jahe merah memiliki manfaat yang lebih besar dibandingkan dengan jenis jahe lain. Rimpang jahe merah mengandung cadangan minyak atsiri berupa lemonin, kamfena, zingiberin, gingerol, shogool dan gingeral. Gingerol dalam jahe merah menyebabkan rasa jahe yang panas dan berkhasiat sebagai menjadi antiinflamasi yang sangat baik bagi tubuh.

Imunomodulator merupakan senyawa yang mampu mempengaruhi sistem kekebalan tubuh manusia, imunomodulator khususnya dari bahan alam perlu dikaji lebih mendalam, karena mahalnya imunomodulator yang tersedia di pasaran. Peningkatan pengembangan senyawa imunomodulator ini akan lebih bermakna apabila disertai dengan kajian yang berhubungan dengan kandungan senyawa aktif termasuk mekanisme kerjanya (Faradilla, 2014)

Pada penelitian ini diharapkan ekstrak memberikan efek imunostimulator. Efek yang akan menguntungkan untuk peningkatan respon imun spesifik dan non spesifik. Pada penelitian terdahulu, ekstrak yang mengandung flavonoid memiliki potensi meningkatkan efek imunomodulator dalam model eksperimental imunitas seluler dan humoral dalam memodulasi sistem kekebalan tubuh pada dosis yang rendah (Phatru Patel et al, 2010). Flavonoid berpotensi sebagai antioksidan yang dapat meningkatkan respon imun, khususnya sebagai mediator eksogen untuk mengaktifkan makrofag (Faradilla, 2014). Makrofag merupakan salah satu sel yang berperan dalam respon imun, berperan fungsional dalam reaksi fagositosis. Dalam melakukan perannya diperlukan bantuan mediator endogen dan eksogen. Sehingga keberadaan flavonoid banyak diperlukan dalam reaksi imunitas.

Dari penelitian Phatel (2010) menyatakan bahwa ekstrak metanol buah mojo (Aegle marmelos L.) efektif meningkatkan efek immunomodulator dalam model eksperimental imunitas seluler dan humural dalam memodulasi sistem kekebalan tubuh. Ahmad (2014) mengatakan bahwa kulit batang mojo dapat meningkatkan fagositosis sel makrofag dan proliferasi sel limfosit.

Penelitian terdahulu (Masniah, 2018) menyatakan bahwa Skrining fitokimia dan perbandingan efektivitas antiinflamasi Jahe Merah (Zingiberis officinale) dengan fraksi, n-Heksana dan Etil Asetat pada tikus putih (Rattus norvegicus) lebih banyak di fraksi sisa memberikan efek antiinflamasi.

Berdasarkan uraian diatas penulis tertarik dan melanjutkan penelitian jahe merah dengan judul: Isolasi Senyawa Aktif dan Uji Aktivitas Ekstrak Jahe Merah (Zingiber Officinale) sebagai Imunomodulator. 


\section{METODE PENELITIAN MATERIAL}

Penelitian meliputi jahe merah segar, dibuat menjadi ekstrak etanol, dikeringkan, Hasilnya dibuat suspensi, ekstrak lalu diberi pada sel makrofag (pengujian fagositosis) dan sel limfosit (pengujian proliferasi) secara in-vitro untuk diujikan efek imunomodulator. Sampel yang diuji pada penelitian ini adalah bagian limpa mencit (Balb/C) jantan. Hewan percobaan dalam penelitian ini adalah mencit dengan kondisi sehat yang diperoleh dari peternakan. Jumlah mencit yang digunakan 50 ekor. Jumlah hewan percobaan tiap kelompok dihitung dengan rumus Federer. Hewan percobaan minimal untuk masingmasing pelakuan sebanyak 3 (tiga) ekor. Hewan uji yang digunakan tiap kelompok 5 ekor untuk mendapatkan data yang lebih banyak.

\section{EKSTRAKSI}

Pembuatan ekstrak etanol jahe merah, Ekstrak etanol jahe merah dibuat secara maserasi dengan menggunakan cairan penyari alkohol $96 \%$.

- 100 bagian ekstrak cair yang akan dibuat $=3000 \mathrm{~g}$

Maka 10 bagian serbuk jahe merah = $300 \mathrm{~g}$

Menurut Farmakope Indonesia Edisi $\mathrm{IV}, \mathrm{Bj}$ etanol $=0,812-0,816$

Maka $\mathrm{Bj}$ rata-ratanya adalah: $\frac{0,812+0,816}{2}=0,814$

- Volume penyari yang digunakan: $\mathrm{V}=\frac{m}{B j}=\frac{3000 \mathrm{~g}}{0,814 \mathrm{~g} / \mathrm{ml}}=3685 \mathrm{ml}$

- Cairan penyari 75 bagian:

$$
\frac{75}{100} \times 3685 \mathrm{ml}=2764 \mathrm{ml}
$$

- Cairan penyari 25 bagian:

$$
\frac{25}{100} \times \mathrm{ml} 3685=921 \mathrm{ml}
$$

Masukkan 300 gram jahe merah yang telah dihaluskan ke dalam wadah kemudian tuangi dengan $2764 \mathrm{ml}$ cairan penyari. Tutup rapat, diamkan selama 5 hari terlindung dari cahaya matahari (selama pendiaman diaduk minimal sebanyak 3 kali). Setelah 5 hari campuran tersebut diserkai, peras dan dibilas ampasnya dengan menggunakan sisa cairan penyari. Dimasukkan ke dalam wadah tertutup rapat, diamkan selama 2 hari di tempat gelap. Enap tuangkan, kemudian maserat diuapkan dengan alat rotary evaporator hingga diperoleh ekstrak kental jahe merah. Ekstrak etanol jahe merah yang diperoleh dilakukan skrining fitokimia.

\section{PENYIAPAN SAMPEL BAHAN UJI}

\section{- Suspensi induk}

Sebanyak $10 \mathrm{mg}$ ekstrak ditambahkan DMSO $100 \mu \mathrm{L}$ hingga homogen. Kemudian ditambahkan dengan laritan medium komplit hingga $900 \mu \mathrm{L}$ dan divortex kembali hingga homogen. Diperoleh konsentrasi suspensi 10000 $\mu \mathrm{g} / \mathrm{ml}$, disebut dengan suspensi induk.

-. Suspensi ekstrak 600 ppm.

Sebanyak $1600 \mu \mathrm{L}$ suspensi induk dimasukkan ke dalam tabung eppendorf dan ditambahkan larutan medium komplit sebanyak $400 \mu \mathrm{L}$.

-Suspensi ekstrak 450 ppm.

Sebanyak $1200 \mu \mathrm{L}$ suspensi induk dimasukkan ke dalam tabung eppendorf dan ditambahkan larutan medium komplit sebanyak $800 \mu \mathrm{L}$.

- Suspensi ekstrak 300 ppm. 
Sebanyak $800 \mu \mathrm{L}$ suspensi induk dimasukkan ke dalam tabung eppendorf dan ditambahkan larutan medium komplit sebanyak $1200 \mu \mathrm{L}$.

- Suspensi ekstrak 150 ppm.

Sebanyak $400 \mu \mathrm{L}$ suspensi induk dimasukkan ke dalam tabung eppendorf dan ditambahkan larutan medium komplit sebanyak $1600 \mu \mathrm{L}$.

\section{PENGUJIAN AKTIVITAS \\ FAGOSITOSIS SEL MAKROFAG}

Isolasi sel makrofag dan pengukuran aktivitas makrofag (Leijh dkk., 1986).

Mencit dieuthanasia dengan eter, kemudian dilakukan pembedahan perut pada mencit dan diambil cairan peritonial, kemudian ditambahkan medium Roswell Park Memorial Institute (RPMI) dengan cara diinjeksikan secara intra peritoneal, kemudian dibiarkan hingga medium menyebar ke seluruh peritonial dan sel makrofag pun terbentuk. Cairan peritonial dikeluarkan dari rongga peritonium menggunakan jarum suntik pada bagian yang tidak berlemak dan jauh dari usus. Semua cairan yang diambil dengan jarum suntik dicampur menjadi satu.

Cairan tersebut kemudian dipindah dalam tabung sentrifugasi. Cairan disentrifugasi pada $1200 \mathrm{rpm}$ selama 10 menit. Endapan diambil dan supernatan dibuang lalu ditambahkan $2 \mathrm{~mL}$ dapar tris amonium klorida. Campuran tersebut kemudian diresuspensi ke dalam $5 \mathrm{~mL}$ medium komplit.

$\begin{array}{llr}\begin{array}{l}\text { Jumlah sel dihitung } \\ \text { hemositometer }\end{array} & \begin{array}{r}\text { dengan } \\ \text { kemudian }\end{array} \\ \text { diresuspensikan } & \text { dengan } & \text { medium }\end{array}$

komplit sehingga didapat suspensi sel dengan jumlah $2,5 \times 10^{6} \mathrm{sel} / \mathrm{mL}$.

Suspensi sel (sel makrofag dan medium komplit) pada plate 24 well yang sebelumnya telah diberi coverslip bulat, diberi $200 \mu \mathrm{L}$ tiap sumuran dan diinkubasi selama 30 menit, kemudian ditambah $800 \mu \mathrm{L}$ medium komplit dan diinkubasi kembali selama 24 jam. Selanjutnya pada wells diganti dengan $500 \mu \mathrm{L}$ ekstrak dengan berbagai macam konsentrasi. Plate di inkubasi selama 1 jam.

Aktivitas makrofag diukur berdasarkan kemampuan memakan atau memfagositosis lateks. Lateks disuspensikan sehingga memiliki konsentrasi 2,5 x $10^{7} \mathrm{~mL}$, kemudian plate dicuci dengan PBS sebanyak 3 kali untuk menghilangkan lateks.

Plate dikeringkan dengan suhu kamar. Setelah kering, masing-masing sumuran difiksasi dengan metanol selama 30 detik dan kemudian coverslip direndam dengan cat Giemsa 20\% selama 20 menit. Tiap sumuran dicuci dengan akuades dan dikeringkan pada suhu kamar. Jumlah latex yang terfagositosis oleh sel makrofag dapat diamati dengan mikroskop cahaya dengan perbesaran 400 kali.

\section{PENGUJIAN AKTIVITAS PROLIFERASI SEL LIMFOSIT}

Isolasi sel limfosit dan uji proliferasi sel limfosit (Ediati dkk., 2008).

Mencit dieuthanasia dengan eter, kemudian dilakukan pengambilan limpa pada mencit kemudian ditambahkan medium Roswell Park Memorial Institute (RPMI), lalu dilakukan sentrifugasi selama 10 menit dengan 
kecepatan 1500 rpm, filtrat dibuang dan endapan disuspensikan dalam $5 \mathrm{~mL}$ dapar tris amonium klorida untuk melisiskan eritrosit. Sel dicampur hingga homogen dan didiamkan pada suhu kamar selama 5 menit. Selanjutnya ditambahkan dengan medium RPMI dan disentrifugasi kembali dengan kecepatan 3000 rpm. Supernatan dibuang, dan endapan yang didapat disuspensikan pada medium komplit hingga volume $5 \mathrm{~mL}$. Sel disuspensikan dalam medium komplit kembali hingga pengenceran seratus kali hingga jumlah sel nya $1,5 \times 10^{6} \mathrm{sel} / \mathrm{mL}$. Selanjutnya sel limfosit siap untuk diuji aktivitasnya dan dikultur dalam inkubator.

Uji proliferasi limfosit ini menggunakan metode MTT-assay. Sebanyak $200 \mu \mathrm{L}$ sel limfosit didistribusikan ke dalam sumuran mikroplat 96-wells sesuai dengan masing-masing kelompok perlakuan kemudian ditambahkan vaksin hepatitis B sebanyak 10 $\mu \mathrm{L} /$ sumuran dan diinkubasi selama 1 jam dalam inkubator. Kemudian ditambahkan ekstrak dengan berbagai konsentrasi pada masing-masing kelompok perlakuan dan diinkubasi kembali selama 48 jam. Setelah diinkubasi, masing-masing sumuran ditambahkan larutan MTT dan diinkubasi selama 4 jam. Reaksi dengan
MTT dihentikan dengan menambah reagen stopper yaitu larutan SDS 10\% dalam asam klorida $0,01 \mathrm{~N}$ sebanyak 50 $\mu \mathrm{L}$ pada tiap sumuran. Selanjutnya diukur absorbansinya dengan mikroplate reader dengan panjang gelombang $550 \quad \mathrm{~nm}$ dan didokumentasikan dengan kamera pada mikroskop.

Identifikasi Kandungan Senyawa dengan LC-MS dan GC-MS

Untuk fraksi yang teaktif dilakukan uji analisis selanjutnya menggunakan LCMS di Pusat Penelitian Kimia-LIPI Jakarta. LC-MS dengan sistem ESI (Electrospray Ionisation) dengan mode positif ion. Sedangkan untuk GC-MS dilakukan di Puslabfor Mabes Polri Jakarta.

\section{HASIL DAN PEMBAHASAN \\ Ekstraksi}

Ekstraksi Jahe Merah diperoleh dari maserasi dengan pelarut etanol. Ekstrak dibuat dengan botol maserasi dengan serbuk jahe merah. Setelah itu dimasukan dalam botol maserasi yang diberi etanol dan campuran tersebut di diamkan selama 5 hari dan dipekatkan sehingga didapatkan ektrak etanol Jahe merah

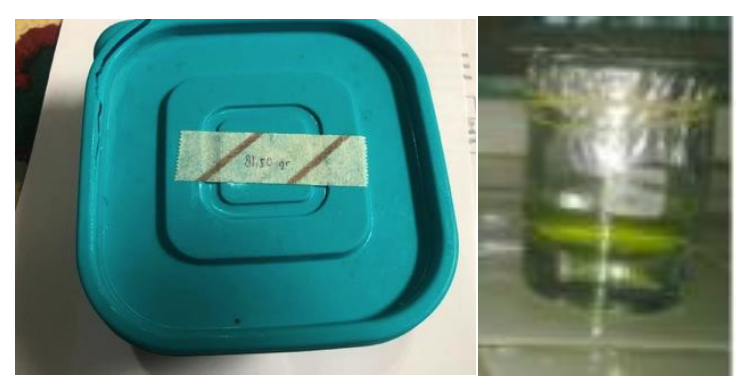

Gambar 1. Ekstrak Jahe merah 
Hasil Ekstrak Jahe Merah yang didapatkan adalah 81,50 gram.

\section{Fagositosis Sel Makrofag}

Pengamatan menggunakan mikroskop akan terlihat makrofag berwarna ungu dan lateks yang berwarna bening. Dan lateks yang terfagositosis akan terlihat berbeda dibandingkan dengan lateks yang tidak terfagositosis.

Gambar 2. Kultur sel makrofag tanpa perlakuan

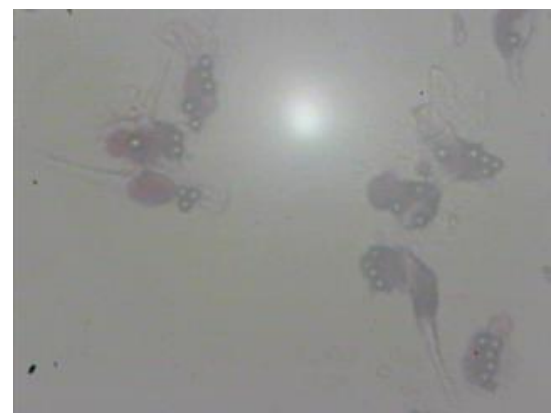

Gambar 3. Kultur sel makrofag dengan perlakuan

\section{Proliferasi Sel Limfosit}

Sebanyak $100 \mu \mathrm{L}$ sel limfosit $(1,5 \times 106$ $\mathrm{sel} / \mathrm{mL}$ ) didistribusikan ke dalam sumuran mikroplat 96-wells sesuai dengan masing-masing kelompok perlakuan kemudian ditambah vaksin hepatitis B sebanyak $10 \mu \mathrm{L} /$ sumuran dan diinkubasi selama 1 jam. Fungsi vaksin hepatitis B untuk meningkatkan respon imun dengan menginduksi sel $\mathrm{T}$ dan sel B. Setelah inkubasi, kemudian ditambahkan ekstrak dan PHA pada masing-masing kelompok perlakuan. Plate diinkubasi kembali selama 48 jam.
Inkubasi ini dilakukan untuk member waktu kepada sel limfosit untuk berproliferasi setelah diberi perlakuan ekstrak dan PHA. Setelah 48 jam, ditambahkan kembali larutan MTT dan diinkubasi selama 4 jam. Sel yang hidup akan bereaksi dengan MTT membentuk warna ungu sehingga mudah untuk mengukur pertumbuhan dan proliferasi sel limfosit. Jumlah sel yang hidup dideteksi dengan microplate reader dan serapannya dinyatakan dengan optical density. 


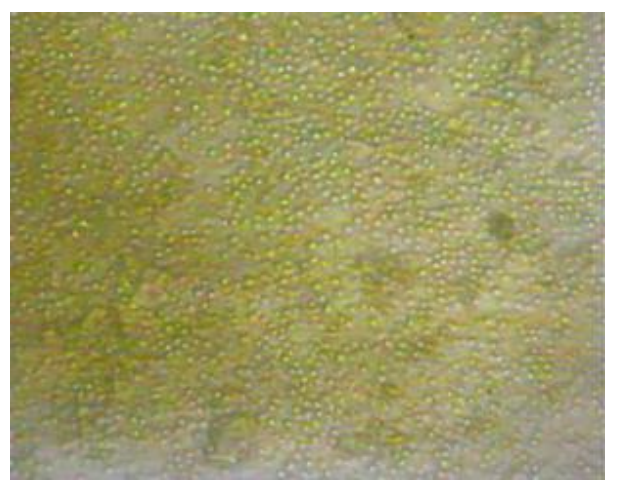

Gambar 3. Sel limfosit yang telah ditambah dengan reagen MTT tanpa perlakuan

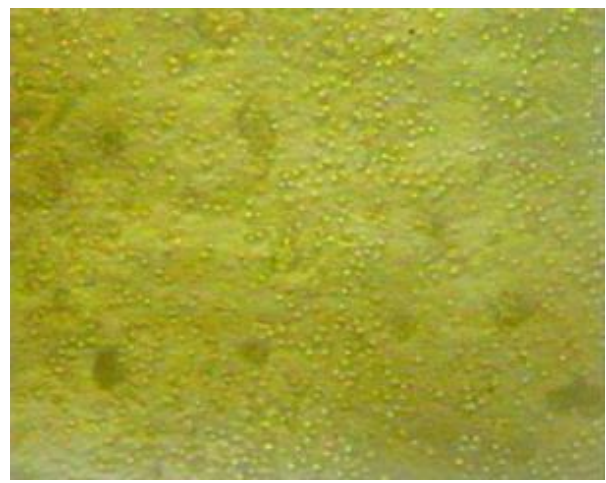

Gambar 4. Sel limfosit dengan pemberian perlakuan

\section{Pembahasan}

\section{Aktivitas Ekstrak Jahe Merah terhadap Fagositosis Sel Makrofag}

Sel Makrofag yang digunakan pada penelitian ini di isolasi dari cairan peritoneal mencit. Sel makrofag yang diambil ini telah terbukti memiliki kepekaan imunitas yang tinggi. Pengambilan sel makrofag dilakukan dengan cara menyuntikkan caira RPMI dengan $\mathrm{pH}$ netral ke dalam rongga peritoneum mencit yang telebih dulu dimatikan menggunakan eter. Larutan RPMI yang digunakan adalah yang dingin dan peritoneum mencit ditekantekan dengan tujuan agar sel makrofag yang menempel pada rongga peritoneum mencit dapat terlepas dan bias diperoleh makrofag dengan jumlah yang optimum. Cairan peritoneal kemudian diambil dengan spuit injeksi, dipilih bagian yang tidak berlemak dan jauh dari usus, cairan yang didapat kemudian ditampung dan di sentrifuge untuk memisahkan sel makrofag dengan sel darah merah.

Jumlah sel dihitung dengan hemositometer kemudian disuspensikan dengan medium komplit sehingga didapat suspensi sel dengan jumlah $2,5 \times 10^{6}$ sel. Pada perhitungan hemositometer, sel yang hidup dan mati diamati di bawah mikroskop, dimana sel yang hidup akan bercahaya (transparan) sementara sel yang mati akan berwarna gelap (hitam).

$$
\text { Pengamatan dilakukan }
$$
menggunakan coverslip sebagai tempat penempelan makrofag, sehingga dapat diamati oleh mikroskop. Suspensi sel (sel makrofag dan medium komplit) pada plate 24 yang telah diberi https://doi.org/10.33759/jrki.v3i2.131 
coverslip, diberikan sebanyak $200 \mu \mathrm{L}$ tiap semuran dan di inkubasi selama 30 menit, kemudian diberikan sebanyak $800 \mu \mathrm{L}$ MK lalu di inkubasi selama 2 jam. Pada sumuran diganti dengan 1000 $\mu \mathrm{L}$ sampel dan di inkubasi selama 24 jam lalu di cuci dua kali dengan RPMI, kemudian ditambah havrix $10 \mu \mathrm{L}$ dan ekstrak $500 \mu \mathrm{L}$ dengan berbagai macam konsentrasi selama 1 jam. In kubasi ini bertujuan untuk suspensi sel dapat menempel di coverslip. Dengan pemberian sampel ini dapat dilihat bagaimana kemampuan sampel terhadap kemampuan fagositosis makrofag terhadap lateks.
Sel dicuci dengan methanol untuk membuat membran makrofag lebih terbuka kemudian sel di cat dengan Giemsa 20\% selama 20 menit hingga zat warna giemsa lebih mudah masuk dan menjadi warna ungu. Dilanjutkan pencucian kembali dan dikeringkan agar sel makrofag yang tidak menempel pada coverslip dapat dibersihkan sehingga tidak mengganggu pengamatan.

Indeks fagositosis makrofag ditetapkan berdasarkan jumlah lateks yang terfagositosis 100 makrofag. Jumlah lateks terfagositosis menunjukkan hasil yang variatif. Kelompok $G$ dengan fraksi 500 ppm dapat meningkatkan kemampuan fagositosis makrofag.

Tabel 1. Jumlah lateks yang difagositosis oleh 100 makrofag

\begin{tabular}{ccccc}
\hline Kel & \multicolumn{3}{c}{ Jumlah lateks } & Rata-rata \\
\cline { 2 - 4 } & R1 & R2 & R3 & \\
\hline A & 22 & 28 & 24 & 24,66 \\
B & 43 & 34 & 33 & 36,66 \\
C & 31 & 26 & 21 & 26 \\
D & 23 & 21 & 36 & 26,66 \\
E & 28 & 35 & 38 & 33,66 \\
F & 38 & 40 & 43 & 40,33 \\
G & 64 & 28 & 49 & 47 \\
\hline
\end{tabular}

Keterangan:

R: Replikasi

A: Kontrol Negarif (DMSO, Sel)

B: Kontrol Positif (Sel, PHA, Engerik)

C: Sel, 100 ppm ekstrak, Engerik

D: Sel, 200 ppm ekstrak, Engerik

E: Sel, 300 ppm ekstrak, Engerik

F: Sel, 400 ppm ekstrak, Engerik

G: Sel, 500 ppm ekstrak, Engerik

Data jumlah lateks yang difagositosis oleh sel makrofag ini selanjutnya dianalisis secara statistik dengan uji one way ANOVA untuk 85 melihat signifikansi peningkatan aktivitas makrofag dari masing-masing kelompok perlakuan. Sebelumnya dilakukan uji untuk melihat normalitas https://doi.org/10.33759/jrki.v3i2.131 
data. Uji tersebut menggunakan Shapiro-wilk karena data yang dimiliki kurang dari-50, data dinyatakan sebagai data yang diambil dari populasi terdistribusi normal jika $\alpha>0,2$ karena uji dilakukan terhadap sel yang merupakan makhluk hidup dan memiliki variasi biologis yang tinggi. Dari data diketahui uji normalitas terlihat semua data terdistribusi normal (Lampiran)

Tabel 2. Uji normalitas data indeks fagositosis makrofag

\begin{tabular}{cc}
\hline Kelompok & Signifikansi \\
A & 0,637 \\
B & 0,174 \\
C & 1,000 \\
D & 0,235 \\
E & 0,567 \\
F & 0,780 \\
G & 0,831 \\
\hline
\end{tabular}

Uji tukey (lampiran) yang dilakukan tersebut untuk analisis perbandingan ganda. Hasil analisis statistik menunjukkan bahwa kelompok $\mathrm{G}$ dengan konsentrasi 500 ppm menunjukkan perbedaan yang signifikan disbanding kontrol positif. Hal ini dapat meningkatkan indeks fagositosis makrofag

\section{Aktivitas Ekstrak Jahe Merah terhadap Proliferasi Sel Limfosit}

Limpa dari mencit sebagai sumber sel limfosit karena merupakan organ limfoid sekunder utama yang berfungsi sebagai tempat utama produksi sel $\mathrm{T}$ dan sel $\mathrm{B}$. Metode yang digunakan pada pengujian proliferasi sel limfosit ini adalah metode MTT-assay yang merupakan metode kolorimetri untuk mengamati proliferasi dan pertumbuhan sel, yang dilakukan dengan prinsip perhitungan sel setelah pewarnaan. Metode ini digunakan karena cepat, sensitive, akurat, dan sampel yang ditetapkan dapat dalam jumlah besar.

Tabel 3. Optical Density Sel Limfosit

\begin{tabular}{ccccc}
\hline Perlakuan & R1 & R2 & R3 & Rata-rata \\
\hline A 500 ppm & 0,503 & 0,506 & 0,479 & 0,496 \\
A 400 ppm & 0,448 & 0,459 & 0,463 & 0,456 \\
A 300 ppm & 0,426 & 0,433 & 0,448 & 0,435 \\
A 200 ppm & 0,415 & 0,418 & 0,416 & 0,416 \\
A 100 ppm & 0,410 & 0,418 & 0,413 & 0,413 \\
B 500 ppm & 0,488 & 0,476 & 0,481 & 0,481
\end{tabular}




$\begin{array}{ccccc}\text { B 400 ppm } & 0,456 & 0,444 & 0,449 & 0,449 \\ \text { B 300 ppm } & 0,409 & 0,434 & 0,413 & 0,418 \\ \text { B 200 ppm } & 0,399 & 0,399 & 0,399 & 0,399 \\ \text { B 100 ppm } & 0,362 & 0,356 & 0,368 & 0,362 \\ \text { C 500 ppm } & 0,388 & 0,391 & 0,393 & 0,390 \\ \text { C 400 ppm } & 0,385 & 0,384 & 0,396 & 0,388 \\ \text { C 300 ppm } & 0,390 & 0,386 & 0,394 & 0,39 \\ \text { C 200 ppm } & 0,395 & 0,391 & 0,390 & 0,392 \\ \text { C 100 ppm } & 0,405 & 0,390 & 0,398 & 0,397 \\ \text { D } & 0,360 & 0,378 & 0,368 & 0,368 \\ \text { E } & 0,403 & 0,399 & 0,389 & 0,397 \\ \text { F } & 0,375 & 0,372 & 0,377 & 0,374\end{array}$

Keterangan:

A: Sel, Ekstrak, MK, Engerik

B: Ekstrak, MK, Engerik

C: Sel, PHA, MK, Engerik

D: Media, MTT

E: Sel, MTT

F: Sel, DMSO

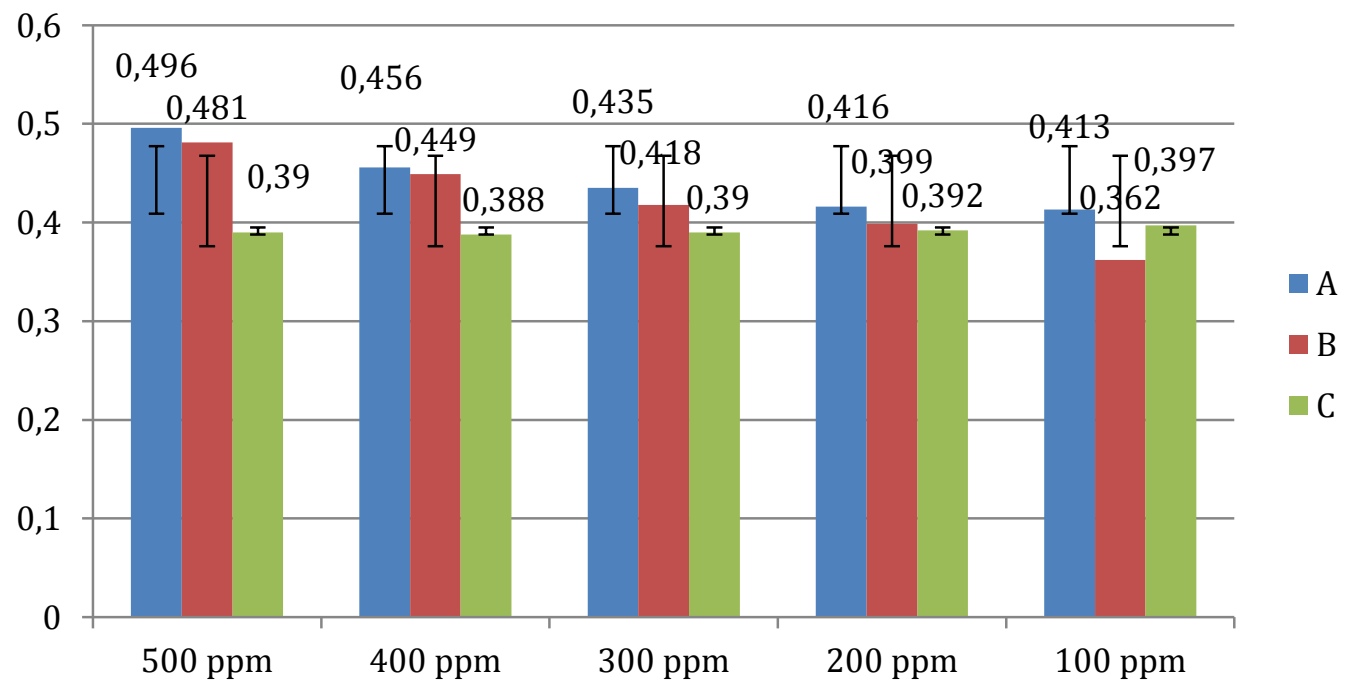

Gambar 5. Grafik proliferasi sel limfosti

Analisis statistik selanjutnya (lampiran) dilakukan untuk melihat signifikansi perlakuan terhadap proliferasi sel limfosit. Analisis dilakukan dengan software SPSS 18 dengan taraf kepercayaan digunakan 95\% ( $\mathrm{p}=0,05)$. Sebelumnya pengujian homogenitas data pada menu 
descriptive statistic dan dihasilkan berupa parameter Kolmogorof smirnov dan Shapiro wilk.

Data dinormalkan dengan cara ditransform ke bentuk $\log 10$. Setelah itu dilakukan analisis homogenitas data kembali pada data yang sudah ditransform. Data hasil transform sudah normal. Selanjutnya analisis dilanjutkan dengan parametrik dengan menu Test of Homogenity of varians. Varians dikatakan homogeny apabila signifikansi > 0,05. Dilanjutkan analisis Post hoc Multiple Comparison menggunakan LSD pada menu One Way ANOVA. Analisis yang dilakukan terhadap transform limfosit memiliki $\mathrm{p}<0,05 \quad(\mathrm{p}=0,000) \quad$ pada ANOVA sehingga secara keseluruhan dapat dikatakan bahwa perlakuan yang diberikan memberikan pengaruh proliferasi terhadap sel limfosit.

\section{Identifikasi Kandungan Kimia dengan GCMS}

Dilakukan analisis menggunakan GCMS (Gas chromatography-Mass spectrometry). GCMS merupakan metode pemisahan senyawa organik yang menggunakan dua metode analisis senyawa yaitu GC (kromatografi gas) untuk menganalisis senyawa secara kuantitatif dan MS (spektrofotometi massa) untuk menganalisis struktur molekul senyawa yang diteliti.

\begin{tabular}{lccc}
\hline Spectrum Source & $\begin{array}{c}\text { Fragmentor } \\
\text { Voltage }\end{array}$ & $\begin{array}{c}\text { Collision } \\
\text { Energy }\end{array}$ & $\begin{array}{c}\text { Ionization } \\
\text { Mode }\end{array}$ \\
Peak (4) in "+ TIC Scan" & & 0 & EI
\end{tabular}

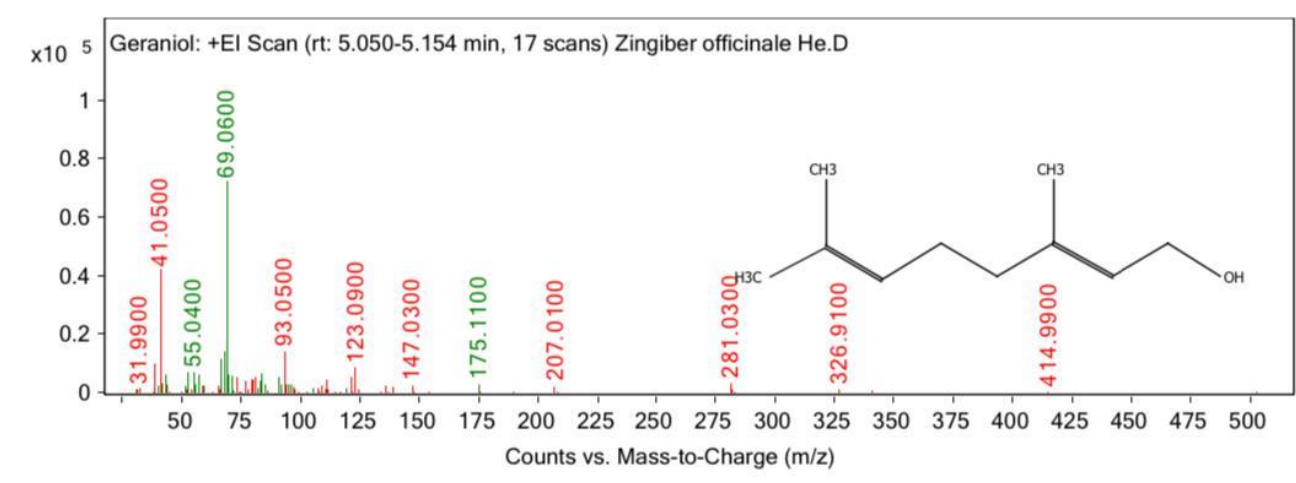

Spectrum Structure Geraniol

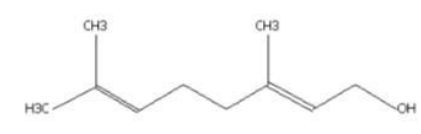

Gambar 5. Spektra MS isolate dari ekstrak dengan GCMS

Pada ekstrak, terdapat 14 Senyawa ekstrak yang dikenal dan teridentifikasi menggunakan GCMS ini. Kromatogram dapat dilihat pada lampiran berbentuk 
gambar dan table. Waktu retensi, plot aream dan persen konsentrasi dipresentasikan masing-masing sebagai berikut: 6-Methyl-2-Heptanol, Furaenol, Cyclohexamine, N-3-butenyl-N-methyl, Imidazole, 2-amino-5-[carboxy)vinyl], Octan-2one, 3-6-dimethyl, 1,3Propanediol, 2-ethyl-2(hydroxymethyl), d-mannose, 2-butanone,4-(4-hydroxy-3methoxyphenyl), Pterin-6-carboxylicacid, Octanal, endo-borneol, L-alphaTerpineol, Geraniol, Zingerone, Acetate

\section{KESIMPULAN}

Kesimpulan dari penelitian ini yaitu Ekstrak etanol jahe merah dapat member efek peningkatan aktivitas fagositosi sel makrofag pada konsentrasi 500 ppm. Ekstrak pada kelompok A meningkatkan proliferasi sel limfosit. Kandungan senyawa aktif yang terdapat pada ekstrak etanol jahe merah diduga Geraniol

\section{UCAPAN TERIMAKASIH}

Pada kesempatan ini, peneliti ingin mengucapkan terima kasih kepada berbagai pihak yang telah membantu terwujudnya penelitian ini :

1. Direktur Poltekkes Kemenkes Medan

2. Ketua Pusat Penelitian dan Pengabdian Masyarakat Poltekkes Kemenkes Medan

3. Ketua Jurusan Farmasi Poltekkes Kemenkes Medan

4. Tim Peneliti

\section{DAFTAR PUSTAKA}

Bratawidjaja KG. 2003. Imunologi Dasar, Edisi 6, Balai Penerbit Fakultas Kedokteran
Universitas

Indonesia; Jakarta.

Departemen Kesehatan RI, Farmakope Indonesia, Edisi IV, Jakarta 1995.

Ediati, Yuniarti, N., \& Soegihardjo, C.J., 2008, Mekanisme Imunomodulator Ekstrak Buah Mengkudu (Morinda citrifolia L.) pada mencit Balb/c yang diinduksi Vaksin Hepatitis B, Majalah Obat Tradisional, 13 (43), dapat diperoleh online melalui http://mot.farmasi.ugm.ac.id/a rtikel-59-mekanismeimunomodulatorekstrakbuah-mengkudumorinda-citrifolia-l-padamencit-balbc-yang-diinduksivaksin-hepatitis-b.html, diakses tanggal 1 November 2019.

Faradilla, et al. 2014 . Immunomodulatory Effect of Polysaccharide fromWhite Turmeric [Curcuma zedoaria(Christm.) Roscoe)] Rhizome , Jurnal Kefarmasian Indonesia, 273-278

Ferrer, 2009. Liquid chromatographyTime of Flight Mass Spectrometry: Principles, Tools and Applications for Accurate Mass Analysis. New York, NJ: Wiley.

Ganong W.F. 1979. Fisiologi Kedokteran. Penerbit BUku Kedokteran EGC., Jakarta.

Gritter FJ et al. 1991. Pengantar Kromatografi (terjemahan K. 
Padmawinata), edisi 2. ITB. Bandung. 107

Hidayat dkk, Kitab Tumbuhan Obat, Penerbit PT.Agriflo, Jakarta Timur, 2013.

Jiao Y.,Wen J.,Yux. 1999. Influence of Flavonoid of Astragalus membrane aceusStem and Leaves on the Function of Cell Mediated Immunity in Mice : Chinese Journal of Integrated Traditional and Western Medicine. Heilongjian University.19 (6): 356-358.

Katzung, B. G. 2007. Basic and Clinical Pharmacology, 10th ed. McGraw-Hill Medical, NewYork, 908-934.

Kresno, S. B. 2001. Diagnosis dan Prosedur Laboratorium.Edisi IV (DenganPerbaikan).Jakarta : FKUI.Ruslidan

Krombach F. Münzing S. Allmeling. A. M., Gerlach, J. T., Behr, J., Dörger, M. 1997. "Cell size of alveolar macrophages: an interspecies comparison".Environ. Health Perspect. 105 Suppl 5 (Suppl 5): 1261-3

Leijh, P.C., Van Furth, R., \& Van Zwet, Th.L., 1986. In Vitro Determination of Phagocytosis and Intracellular by Polymorphonuclear and Mononuclear Phagocyte, dalam Herzenberg, L.A., Weir, D.R., Blackwell, C., (Eds.) Handbook of Experimental Immunology, 121, Blackwell Scientific Publication, London
Marry J. 2002. Thyroid Guide, Understanding the Immune System.

Patel P. 2010. Immunodulatory activity of methanolic fruit extract of Aegle marmelos in experimental animals, Saudi Pharmaceutical Journal, Vol 18, 161-165

Pavia, Donald L., Gary M. Lampman, George S. Kritz, Randall G. Engel (2006). Introduction to Organic Laboratory Techniques (4th Ed.). Thomson Brooks/Cole. pp. 797-817.

Richard A. 2000. Kuby Immunology. 4th edition. New York.

Spelman K., Burns J., Nichols D., Winters N., Ottersberg S., dan Tenborg M. 2006. Modulation of Cytokine Expression by Traditional Medicines : A Review of Herbal Immunomodulator, Alternative Medicine Review, 11 (2): 12850.

Syamsuhidayat dkk, Inventaris Tanaman Obat, Departeman Kesehatan RI, Badan.

Tjay H.T dan Rahardja K, Obat-obat Penting, Edisi VI, Gramedia Jakarta, 2008.

Thurman E. 2003. Liquid chromatography/mass spectrometry, MS/MS and time of flight MS: analysis of emerging contaminants. Columbus, $\mathrm{OH}$ : American Chemical Society. 
Towaha, 2010, SomJawa (Talinumpaniculatum) Ginseng Indonesia Penyembuh Berbagai Penyakit. Warta Penelitian dan Pengembangan Tanaman, 16

Yohnston RB., 1993, Monocytes and macrophages. Dalam: Lachman PJ, Keith DP, Rosen FS, Walport MJ, penyunting. Clinicial aspects of immnology, Vol 1 (5), Oxford.
Wagner, H. 1989. Immunostimulans from Higher Plants (recent advances), in Biologically Active Natural Products, K. Hostettman and P. J. Lea (Eds), Clarendon Press, Oxford, 127141.

Wirawan, S dan Erwin, S. 1996.

Pemeriksaan Laboratorium

Hematologi Sederhana. Edisi II.

Jakarta: Fakultas Kedokteran

Universitas Indonesia 